\title{
Osobitosti koncepcije biografskih članaka u Leksikonu podunavskih Hrvata - Bunjevaca $i$ Šokaca
}

\author{
Slaven Bačić \\ Hrvatsko akademsko društvo, Subotica \\ slaven.bacic@yahoo.com
}

\begin{abstract}
SAŽETAK: Velik dio Leksikona podunavskih Hrvata - Bunjevaca i Šokaca, prvoga leksikografskoga projekta hrvatske manjine izvan matične domovine, koji izlazi u Subotici od 2004. godine, čine biografski članci. Specifičnost ovoga leksikona, kao svojevrsnoga regionalnoga leksikona, uvjetovala je pristup istraživanju i prezentaciji biografija koji se donekle razlikuju od biografskih uzusa leksikografske obrade na nacionalnoj razini. U radu se navode najvažnije osobitosti koncepcije biografskih članaka u Leksikonu te ih obrazlaže. Riječ je ponajprije o imenima roditelja ulaznika, odnosno osoba koje se obrađuju, zatim kako se kroz životni put, rad ili znanstveni interes reflektira njihova povezanost sa zavičajem, a katkada o tome svjedoči i mjesto gdje su pokopane. Posebno se naglašavaju razlozi zašto je prilikom odabira ulaznika u Leksikon prihvaćeno načelo etničkoga podrijetla, a ne nacionalnoga osjećaja, te se objašnjava drugačija koncepcija biografija Hrvata iz Hrvatske u odnosu na podunavske Hrvate, zemljopisno omeđene područjem predmeta Leksikona (međuriječje Dunava i Tise). Upućuje se i na važnost uključivanja biografija pripadnika drugih naroda (Mađara, Srba) i metodološko koncipiranje tih članaka. Također se obrazlažu načelno nepostojanje donje dobne granice za uvrštavanje u Leksikon, različita koncepcija obrade povijesnih ličnosti i suvremenika te još neke osobitosti.
\end{abstract}

Ključne riječi: Leksikon podunavskih Hrvata - Bunjevaca i Šokaca; biografski članci; podunavski Hrvati; Bunjevci; Šokci

\section{Uvod}

Leksikon podunavskih Hrvata - Bunjevaca $i$ Šokaca, koji izlazi u Subotici od 2004. godine, osobit je leksikografski projekt po više osnova. Od inicijalnoga sastanka u studenome 2001. godine te tijekom pripremnih radnji, sastanaka, konzultacija i izrade inicijalnoga abecedarija u naredne dvije godine, utvrđeni su okviri rada na ovom leksikografskom projektu: geografski, ne ograničava se na postojeće državne granice jer obuhvaća prostor u međuriječju Dunava i Tise, od Senandrije (mađ. Szentendre, srp. Sentandreja) na sjeveru pa do Novoga Sada na jugu; etnički, predmet jesu pripadnici hrvatske etničke zajednice na ovome prostoru koji se danas, a osobito u proš- 
losti, različito imenuju (podunavskih Hrvati, bački Hrvati, Bunjevci, Šokci, Dalmatini, Raci, Iliri, Mađari slavenske rase, Srbi-Bunjevci itd.); povijesno, hrvatske etničke zajednice na ovako određenome prostoru (tzv. ugarsko Podunavlje) povezuje zajednička prošlost, koja ih razlikuje od Hrvata u drugim nekadašnjim ugarskim i hrvatskim županijama; sadržajno, on nije samo biografski leksikon, već obrađuje i različite udruge, časopise i novine, toponime, pojedine etnografske pojmove, a sadržava i velike pregledne pa i makropedijske članke, koji se obrađuju iz ovako teritorijalno određene hrvatske vizure. ${ }^{1}$ Da je riječ o osobitom hrvatskom leksikografskom pothvatu, potvrđuju i činjenice da je to prvi leksikografski projekt jedne hrvatske manjinske zajednice ${ }^{2}$ te kontinuitet rada na njemu. ${ }^{3}$

U dosadašnjih četrnaest tiskanih svezaka, skromne grafičke opreme i različitoga opsega, koji su tiskani u razdoblju od 2004. do 2019. godine, na 1545 stranica obrađena je polovica slova abecede (A-K) u 1766 članaka, koje prate 1023 ilustracije te 127 uputnica. ${ }^{4}$ Ne umanjujući važnost ostalih članaka u Leksikonu podunavskih Hrvata - Bunjevaca i Šokaca, biografije predstavljaju svakako njegov najvažniji dio. Naime, u dosadašnjih 14 svezaka objavljeno je ukupno 826 biografskih članaka, ${ }^{5}$ što, ne samo segmentarno, čini daleko najopsežniji dio ovoga leksikona (u odnosu na broj članaka o udrugama, listovima i časopisima, toponimima, etnografskim pojmovima i sl.), jer gotovo polovica ukupnoga broja natuknica jesu biografije. Uostalom, biografski članci vjerojatno jesu i najvažniji dio ovoga leksikona, koji će najčešće biti predmetom istraživanja onih koji se bave Hrvatima na ovom području, dok će razmjerno manja pozornost biti posvećena tiskovinama, etnografskim temama, geografskom nazivlju ili makropedijskim prilozima.

Uza sve dileme pred kojima su se inicijatori, članovi uredništva i suradnici Leksikona podunavskih Hrvata - Bunjevaca i Šokaca našli na početku rada (među ostalim, to je bio čak i naslov!), bila je i ona koja se ticala koncipiranja biografskih članaka. Upravo je specifičan teritorijalni opseg uvjetovao osobit pristup istraživanju i predstavljanju biografija osoba koje su donekle različite od biografskih uzusa leksi-

1 Opširnije o koncepciji ovoga leksikografskog projekta usp. Bačić 2004. i 2010a. Svi dosad izišli svesci dostupni su u pdf formatu na internetskoj stranici Hrvatskoga akademskoga društva na poveznici http://www.had.org.rs/leksikon.php

2 Ovo se, dakako, ne odnosi na Hrvate u Bosni i Hercegovini, koji nisu nacionalna manjina, već konstitutivni narod.

3 Potaknut rezultatima Leksikona podunavskih Hrvata - Bunjevaca i Šokaca, prvi svezak Biografskoga leksikona Hrvata istočnoga Srijema (A-Fur), u izdanju Libera editio d.o.o. iz Zagreba i Hrvatskog akademskog društva iz Subotice, izišao je 2011. godine, ali je rad na njemu prekinut. O nekim razlozima prestanka izlaženja ovoga leksikona usp. Bara 2018.

4 Za podrobniju analizu dosadašnjih rezultata usp. Bačić 2020. Petnaesti svezak (L-Mal), u tisku, broji 165 članaka.

5 Petnaesti svezak (L-Mal), u tisku, ima 164 stranice, a od ukupno 165 članaka, 92 jesu biografska. 
kografske obrade na nacionalnoj razini. Neke od specifičnosti anticipirane su još u fazi prikupljanja inicijalnoga abecedarija, dok se dio njih zapravo pojavio tijekom samoga rada na Leksikonu i njegova uređivanja. U daljnjem izlaganju navest ćemo najvažnije osobitosti koncepcije biografskih članaka u Leksikonu te ih potom obrazložiti.

\section{Načelo etničkoga podrijetla}

Metodološki je najvažnije bilo prihvaćanje načela etničkoga podrijetla, umjesto nacionalnoga osjećaja prilikom odabira osoba za uvrštavanje u Leksikon. Naime, nije bilo dileme da će u Leksikon biti uvršteni oni bački Bunjevci i Šokci koji su se nacionalno osjećali odnosno osjećaju Hrvatima, ali je složeno bilo pitanje kako pristupiti onim osobama koje se nacionalno tako nisu osjećale, odnosno ne osjećaju se, a potječu iz istih porodica, čak i obitelji. Primjerice, dio ih se danas identificira kao samostalna etnička skupina Bunjevaca, koja je danas pravno priznata kao posebna nacionalna manjina u Srbiji (čak i sa svojim tzv. bunjevačkim jezikom) i negira bilo kakvu vezu s Hrvatima. Uz njih, tu su i osobe koje su se, za razliku od svojega etničkoga podrijetla, nacionalno osjećale, odnosno osjećaju, čak i pripadnicima drugih većih naroda, tj. nacionalno se izjašnjavaju kao Mađari ili Srbi (neki katoličke vjere, drugi pak prešli u pravoslavnu vjeroispovijed), nisu ni govorili ili pak više ni ne govore hrvatski, bilo novoštokavskim ikavskim ili slavonskim dijalektom bilo standardnim jezikom, već su potpuno, prije ili kasnije, postali dijelom mađarske ili srpske nacije i uopće nihovih kultura.

Odlučili smo se za inkluzivan pristup, držeći da je opravdano i takve osobe uvrstiti u Leksikon, budući da ilustriraju sudbinu hrvatskoga naroda na ovome području jer je njihova nacionalna sudbina posljedica asimilacije i odnarođivanja. Primjerice, brojni članovi razgranate plemićke porodice Latinović (u oba svoja ogranka boršodskom i kaćmarskom $)^{6}$ u najvećoj mjeri mađarizirali su se još u kasnofeudalnom razdoblju. No, mnogi njihovi članovi bili su visoki lokalni i županijski dužnosnici, vojni časnici različitoga ranga, a neki čak i članovi najviših državnih tijela u Ugarskoj. Ukoliko bi propustili obraditi članove ove porodice, ne samo da bi jednostavno izostali podatci o njima, već su oni ujedno i ilustracija za druge natuknice u Leksikonu, poput asimilacije ili mađarizacije. S druge strane, postoje i primjeri, istina ne odviše brojni, pojedinaca koji se kao Bunjevci nacionalno smatraju Srbima, pri čemu neki tek kao Srbi katoličke vjere, dok su drugi čak i vjerski konvertirali u pravoslavnu vjeroispovijed, poput najvažnijega predstavnika ove struje, Albe Kuntića. Poseban slučaj predstavlja danas raširen slučaj onih vojvođanskih Bunjevaca koji se nacionalno osje-

6 Prema mjestima Boršot (mađ. Bácsborsod) i Kaćmar (mađ. Katymár), koja su poslije Trianonskoga mirovnoga sporazuma ostala u Mađarskoj. 
ćaju samo kao Bunjevci i, kao rezultat niza povijesnih ${ }^{7}$ i socioloških razloga, negiraju bilo kakve veze s Hrvatskom i hrvatski nacionalni osjećaj. I ovdje je također zauzeto stajalište kako i takve osobe treba uvrstiti u Leksikon, $\mathrm{s}$ time da, kako se u najvećem broju radi o živim osobama, tome prethode konzultacije s njima, odnosno ukoliko su preminuli, s članovima njihovih obitelji. Pritom neki izričito odbijaju da se o njima piše, pa takve osobe nisu uvrštene u Leksikon, dok oni koji su s time suglasni surađuju osobno (ili članovi njihovi obitelii) u izradi članka. No, ovaj princip nije dosljedno proveden na cijelom geografskom opsegu Leksikona - dok ovo vrijedi za Bunjevce iz vojvođanskoga dijela Bačke, suradnici Leksikona iz Mađarske drže da takvim osobama nije mjesto u objektivno hrvatskome leksikonu (slično drže i za one santovačke Šokce koji su prešli u pravoslavnu vjeru koncem XIX. stoljeća) ${ }^{8}$ i za njih ne dostavljaju priloge te se ova skupina osoba ne uvrštava u Leksikon (inače je ovakvih Bunjevaca u Mađarskoj vrlo malo, uglavnom su iz Kaćmara, gdje je jedno vrijeme kulturni život među Hrvatima vodilo nekoliko prosrpski orijentiranih Bunjevaca i Srba).

\section{Imena roditelja, povezanost sa zavičajem, mjesto pokapanja}

Kada je riječ o strukturi biografskoga članka, u člancima o Hrvatima koji su rođeni na zemljopisno omeđenom području Leksikona na početku teksta uvijek se navode i imena njihovih roditelja, s djevojačkim prezimenom majke. Iako je dosljedna primjena ovoga načela rjeđa u leksikografskoj praksi, nije i nepoznata: primjerice Židovski biografski leksikon, čija je radna verzija dostupna na mrežnim stranicama Leksikografskoga zavoda, ${ }^{9}$ ili pak tiskani Istarski sportski biografski leksikon ${ }^{10}$ i najnoviji Prilozi za biografski leksikon Novog Vinodolskog, ${ }^{11}$ a nedosljedno je proveden i u Enciklopediji Novoga Sada. Iako se ovi podatci mogu činiti nepotrebnima, oni ne govore samo o podrijetlu osoba, već znaju odrediti i pravce njihova profesionalnoga djelovanja, a često i nacionalnoga osjećaja. Primjerice, Titus Mačković, najpoznatiji subotički ar-

\footnotetext{
7 Za povijesne razloge usp. Bačić 2010b..
}

8 Tzv. santovački slučaj, kada je višegodišnji spor hrvatskih i madžarskih vjernika u Santovu (mađ. Hercegszantó, selo koje je poslije Trianonskoga mirovnoga sporazuma ostalo u Mađarskoj) kulminirao povećanjem broja misa na mađarskom jeziku, uz istodobno smanjenje broja misa na hrvatskom jeziku, u santovačkoj crkvi Uznesenja Blažene Djevice Marije. Nakon bezuspješnih žalbi santovačkih Šokaca višim crkvenim instancama te agitiranja pravoslavnih svećenika iz Sombora, dio santovačkih Šokaca 1899. iz protesta prema mađarizatorskoj politici Kalačko-bačke nadbiskupije prešao je na pravoslavnu vjeru. Veći dio ovih Šokaca se, što se često prešućuje u historiografiji, u narednim godinama vratio na katolicizam. Jedan od poznatijih predstavnika santovačkih Šokaca koji su ostali u pravoslavlju jest Radovan Jelašić, guverner Narodne banke Srbije 2004-10. Više o santovačkom slučaju usp. Pekić 1930., Mandić 1999.

\footnotetext{
9 https://zbl.lzmk.hr/ (pristupljeno 10. X. 2020)

10 Hemar 2011.

11 Zoričić 2020.
} 
hitekt i graditelj s konca XIX. stoljeća iz mješovitog je hrvatsko-mađarskoga braka, a sâm je bio u mješovitom hrvatsko-srpskom braku. To je uvelike odredilo njegov nacionalni osjećaj jer je ostao građanski orijentiran, tj. privržen zadanom državnom okviru, tj. mađarskoj državnoj ideji. A to je onda utjecalo i na njegova sina Benedikta, koji se onda u novom jugoslavenskom državnom okviru na ideološko-političkom planu izjašnjavao se za Mađara i zastupao krajnje desna promađarska stajališta, za vrijeme obnove madžarske vlasti 1941-44. obnašao je funkciju u gradskoj civilnoj vlasti, zbog čega je nakon dolaska komunista stradao u valu egzekucija bez sudskih presuda protiv tzv. narodnih neprijatelja. S druge strane, nemali broj suvremenih biografija osoba koje su rođene u zadnjih pedesetak godina iz mješovitih su hrvatsko-srpskih brakova, i ta je tendencija vidljiva kada se čitaju biografije suvremenika, osobito iz kuta asimilacije. Danas se potomci iz takvih zajednica nacionalno ne identificiraju po ocu, kako je to bilo tradicionalno, nego se ili nacionalno ne identificiraju ili, ako se pak identificiraju, onda je to prema zadanom državnom okviru, ovoga puta srpskom - najčešće kao Bunjevci, rjeđe kao Srbi. U daljnjoj strukturi članka, prilikom opisa djelatnosti osobe, naglašava se dio njegova životnoga puta, profesionalnoga ili znanstvenoga interesa koji je posvećen zavičaju odnosno zavičajnim temama. Na koncu, u jednom broju članaka navodi se i mjesto gdje su osobe pokopane. Važnost toga nije samo za budućnost, kada npr. za stotinjak godina to bude nepoznat ili manje dostupan podatak, već ovaj podatak katkada daje i određene informacije o osobi. Tako neki podunavski Hrvati, iako su živjeli ili radili u Hrvatskoj, odlučili su biti pokopani u mjestu rođenja (primjerice, akademik Gaja Alaga pokopan je u rodnom Lemešu, srp. Svetozar Miletić), što govori o njihovoj vezanosti za zavičaj. S druge strane, kada je riječ o podunavskim Hrvatima koji su svoj studentski i radni vijek proveli u Zagrebu, pokop u glavnom gradu Hrvatske označava i njihovo opredjeljenje i snažne veze s Hrvatskom. Ili pak splet životnih okolnosti, kao što je slučaj književnoga povjesničara Geze Kikića, koji je nakon sloma hrvatskoga proljeća preselio na Pelješac (Hodilj kraj Stona), gdje je preminuo i pokopan. Postoje i slučajevi kada posvećenost zvanju određuje mjesto pokopa daleko od zavičaja, kakav su primjerice slučajevi časne sestre i misionarke Mire Baraković te isusovca i misionara Marina Kovačeva, koji su pokopani u Argentini odnosno Kolumbiji, gdje su proveli desetljeća u misionarskome radu. Mjesto pokopa također može govoriti i o važnosti osobe, primjerice u budućim člancima o književniku Anti Sekuliću, liječniku Stjepanu Skenderoviću te pravniku i diplomatu Petru Šarčeviću svakako bi trebao naći mjesto podatak da su pokopani u grobnicu bačkih Hrvata u mirogojskim arkadama.

\section{Drugačija koncepcija biografija Hrvata iz Hrvatske}

Koncepcija biografija Hrvata rođenih izvan zemljopisno određenoga područja Leksikona, a koji su živjeli ili djelovali na zemljopisno omeđenom području predmeta 
Leksikona (međuriječje Dunava i Tise) ili se tek samo dio njihove djelatnosti i života koji se odvijao u Hrvatskoj reflektirao u nekom trenutku na podunavske Hrvate, donekle je drukčija odnosu na biografske članke o samim podunavskim Hrvatima. U prvom redu to je vidljivo na samome početku članka, u kojima se ne bilježe imena njihovih roditelja jer se eventualnim navođenjem tih podataka ne mogu posredno ili neposredno ne saznavati već rečeni podatci koji su važni ponajprije za same podunavske Hrvate. Osim toga, budući da su lokalni suradnici Leksikona u pravilu duboko ukorijenjeni u svoje zavičajne prostore, znaju što znači kada je netko podrijetlom iz pojedinih porodica, međutim toga nema ili takav interes ne postoji kada su u pitanju osobe koje ne potječu generacijski s ovoga podneblja. Usto, takvi su podatci kod Hrvata rođenih izvan međuriječja Dunava i Tise u krajnjoj liniji i suvišni, primjerice, u tekstovima o Nikoli Zvonimiru Bjelovučiću, Većeslavu Holjevcu ili Mladenu Lorkoviću, koji su u svojim djelima o Hrvatima pisali i o podunavskim Hrvatima. U biografskim člancima o Hrvatima koji su podrijetlom izvan međuriječja Dunava i Tise, osim općih podataka koji se mogu naći u drugim leksikografskim djelima izdanima u Hrvatskoj, naglasak, odnosno posebna pozornost posvećena je razlozima zbog kojih su uvršteni u Leksikon podunavskih Hrvata. Dakle, struktura članaka o takvim osobama ne sadržava podatke o njihovim roditeljima, već se biografije fokusiraju na znanstveni, politički ili drugi interes koje su takve osobe pokazivale prema podunavskim Hrvatima.

\section{Struktura članaka o pripadnicima drugih naroda}

Gore opisano prihvaćeno načelo inkluzivnosti ne odnosi se samo na najšire shvaćeni pojam podunavskih Hrvata. Još od samih početaka rada na Leksikonu nedvojbeno je držano važnim obraditi i pripadnike drugih naroda (prije svega Mađare i Srbe, ali i ne samo njih) bez obzira jesu li rođeni u međuriječju Dunava i Tise, koji su iz različitih razloga, pozitivnih ili negativnih, važni za podunavske Hrvate. No, i ovi su članci metodološki drukčije koncipirani. Osim općih leksikografskih podataka o ovim osobama (među ostalim, kao i kod Hrvata rođenih izvan međuriječja Dunava i Tise, niti se za njih ne navode imena roditelja) koji zauzimaju manji dio članka, naglasak jest na njihovoj povezanosti s podunavskim Hrvatima. Primjeri to najbolje ilustriraju. Kada je o Srbima riječ, među različitim biografskim prilozima, važni su biografski članci o Vuku Stefanoviću Karadžiću i Dragoslavu Đorđeviću. Fokus članka o Vuku Karadžiću jest njegova jezično-politička ideja o Srbima tri zakona koja do danas utječe ne samo na srpski nacionalni program nego i na bačke Bunjevce i Šokce. Srbijanski pak časnik Dragoslav Đorđević, nakon povlačenja demarkacijske crte savezničkih snaga prema austrougarskim snagama u jesen 1918. godine, doselio je u Suboticu i tu gotovo deset godina kao član Narodne radikalne stranke znatno utjecao na političkih život subotičkih Hrvata. Kada je već riječ o ovome vremenskom 
razdoblju, znakovit je i članak o francuskom generalu Franchetu d'Espereyu, čijih je nekoliko smjelih odluka koncem Prvoga svjetskog rata, napose onoj o određivanju spomenute demarkacijske crte, bitno utjecalo na kasnije određivanje državne granice na području na kojem su živjeli bački Hrvati i njihovu daljnju sudbinu, a koje je provedeno u mirovnome sporazumu potpisanom 4. lipnja 2020. u versailleskome dvorcu Trianon. Ili, ako je riječ o Mađarima, uvršteno je više mađarskih etnografa koji su u vrijeme Austro-Ugarske pisali o Hrvatima iz tadašnjih južnougarskih županija, ali i političara, poput biografije Miklósa Horthyja, u kojoj je opisana njegova denacionalizacijska politika odnosa prema različitim hrvatskim etničkim skupinama u poslijetrianonskom razdoblju u Mađarskoj. Još jedan element posebnoga pristupa leksikografske obrade osoba koje nisu Hrvati jesu ilustracije. Naime, ukoliko biografski članak o njima prati ilustracija, to nisu fotografije tih osoba, već neki drugi momenti koji ih vezuju za podunavske Hrvate, poput nekoga njihova djela, novinskih napisa i sl. Izuzetak je bio članak o Slavku Kuzmanoviću, jedinome srpskom autoru koji je poslije Drugoga svjetskog rata bačke Bunjevce nedvojbeno smatrao Hrvatima, za razliku od svih drugih srpskih publicista i znanstvenika koji su ovo implicitno ili izrično osporavali, odnosno osporavaju.

\section{Nepostojanje donje dobne granice}

Među osobitim pristupima u odabiru biografija za uvrštavanje $\mathrm{u}$ Leksikon jest i načelno nepostojanje donje dobne granice, kakva primjerice postoji u Hrvatskom biografskom leksikonu ili Srpskom biografskom rečniku, u kojima se objavljuju biografije osoba koje su rođene do 1945. godine. Nepostojanje donje dobne granice odnosi se u najvećoj mjeri na biografske članke o suvremenicima, odnosno na osobe koje su žive u vrijeme kada se o njima piše biografski članak. Usvajanje ovakvoga pristupa rezultat je odluke da Leksikon izlazi sukcesivno u svescima, te posljedične vremenske dužine rada na Leksikonu, čime se izbjegava ne samo već ranije uočeni problem u leksikografskoj literaturi kako Leksikon na koncu ne bi sadržavao biografije osoba koje uglavnom više nisu žive, već i opasnost da neki važniji suvremenici budu izostavljeni samo iz načelnoga razloga da su rođeni jednu godinu ili desetljeće nakon potencijalne dobne granice. Ovakvo opravdanje osobito vrijedi za sportaše koji svoj doprinos daju u mlađoj životnoj dobi, za razliku od primjerice znanstvenika, čiji je vrhunac znanstvenoga rada uglavnom u zrelijoj dobi.

\section{Različita obrada povijesnih osoba u odnosu na suvremenike}

U svezi s ovim povezano je i pitanje različite koncepcije obrade povijesnih ličnosti i suvremenika. Biografije suvremenih osoba (osim sportaša) u pravilu su kraće, iz nekoliko razloga. Najvažniji je što objektivna ocjena nečijega djelovanja te ostvarenih 
rezultata zahtijeva vremensku distancu. No, postoje i subjektivni razlozi jer je bilo (istina pojedinačnih) slučajeva kada su obrađeni suvremenici predbacivali uredništvu što je biografski članak o njima prekratak (u odnosu na znatno duži dani prilog) ili su se pak javljali upiti i usporedbe zbog čega je biografski članak o nekoj drugoj osobi duži od članka o njemu. Slično kao i kod biografija osoba koje nisu Hrvati, prihvaćen je pristup da se, kao jedna od distinkcija u odnosu na povijesne osobe, fotografije osoba koje su žive u vrijeme izdavanja Leksikona uglavnom ne objavljuju, već samo za povijesne osobe. Umjesto fotografije ulaznika, kao ilustracija uz njegovu biografiju objavljuje se neki dio njegova opusa, kao što su knjiga (uz biografski članak o Jovanu Erdeljanoviću objavljena je naslovnica njegova djela O poreklu Bunjevaca), slikarsko ili kiparsko djelo i sl. Iznimno, za neke od živih osoba jesu uvrštene i fotografije, no samo ako je njihov profesionalni prinos u vrijeme pisanja biografije bio i završen (primjerice svećenik Andrija Kopilović).

\section{Appendix}

Kada je od 12. sveska Leksikona počelo objavljivanje svojevrsnoga appendixa na kraju svakoga sveska s člancima koji su izostavljeni iz ranijih svezaka (primjerice, ovakav pristup primijenjen je u enciklopediji Novoga Sada), koji je naslovljen Dopune, njegov su najveći dio zauzimale biografije. ${ }^{12}$ Ponekad je njihovo izostavljanje iz osnovnoga sveska posljedica ne samo objektivnoga propusta već i svjesnoga pristupa, primjerice kod iznimnih mlađih sportaša, čiji se najbolji rezultati očekuju tek u budućnosti, te je ostavljeno da se biografski članci o njima objave u okviru Dopuna u nekome od narednih svezaka Leksikona.

\section{Zaključak}

Osobitost Leksikona podunavskih Hrvata - Bunjevaca $i$ Šokaca, kao specifičnoga regionalnoga, ali ujedno i etničkoga odnosno nacionalnomanjinskoga leksikografskoga djela, nevezanoga za današnje političke granice, uvjetovala je i osobit pristup u izradi, među ostalim, i biografskih članaka. Najvažnije je načelo inkluzivnosti, koje podrazumijeva da se u Leksikon, uz osobe koje se nacionalno osjećaju Hrvatima, uvrštavaju i osobe hrvatskoga etničkoga podrijetla koje se kao rezultat asimilacije danas nacionalno osjećaju pripadnicima drugih naroda, kao i da se obrađuju biografski članci o pripadnicima drugih naroda čije je djelovanje imalo utjecaj na povijest podunavskih Hrvata. Biografije podunavskih Hrvata sadržavaju i imena roditeljâ, dok to nije slučaj s Hrvatima koji nisu rođeni u međuriječju Dunava i Tise, niti s pripadnicima

12 U Dopunama 12., 13. i 14 sveska objavljeno je ukupno 27 članaka, dok 15. svezak u tisku sadržava 11 natuknica uvrštenih u Dopune. 
drugih naroda. Slično, fotografije osoba uz biografske članke u pravilu su ograničene samo na podunavske Hrvate, a ne i na ostale Hrvate ili pripadnike drugih nacija, a usto se one objavljuju, u pravilu, samo uz biografske članke osoba koje više nisu žive, ili ukoliko je njihov radni i stvaralački vijek završen. Umjesto fotografija osobe, ove biografske članke prate druge vrste ilustracija, primjerice knjige koje su napisali i sl. Naglasak na sadržaju biografskih članaka jest djelovanje i utjecaj tih osoba koji je važan za podunavske Hrvate. Zbog sukcesivnoga izlaženja svezaka Leksikona, za razliku od nekih drugih leksikografskih izdanja, ne postoji donja dobna granica za uvrštavanje osoba u Leksikon.

\section{LITERATURA}

Bačić, Slaven (2004). Predgovor, Leksikon podunavskih Hrvata - Bunjevaca i Šokaca, 1. sv., Hrvatsko akademsko društvo, Subotica, str. V-VIII.

Bačić, Slaven (2010a). Osobit leksikografski projekt: Leksikon podunavskih Hrvata - Bunjevaca i Šokaca, Identitet bačkih Hrvata, Hrvatski institut za povijest - Hrvatsko akademsko društvo, Zagreb-Subotica, str. 357-364.

Bačić, Slaven (2010b). Nacionalno-integracijski procesi Bunjevaca u Bačkoj i ugarskom Podunavlju, Godišnjak za znanstvena istraživanja Zavoda za kulturu vojvođanskih Hrvata, br. 2, str. 65-76.

Bačić, Slaven (2020). 15 godina Leksikon podunavskih Hrvata - Bunjevaca i Šokaca, u: Zbornik radova sa Znanstveno-stručnoga skupa Etnokulturni identitet Hrvata u Vojvodini: povijesni i suvremeni procesi održanoga u Zagrebu i Subotici od 9. do 11. listopada 2019, Hrvatsko katoličko sveučilište, Zagreb, str. 51-62.

Bara, Mario (2018). Što se dogodilo s projektom 'Biografskog leksikona Hrvata istočnog Srijema' nakon izdavanja prvog sveska 2011. godine? Treba li na nam leksikon?, Zov Srijema, 24, 97/98, Zagreb, 2018, str. 46-47.

Hemar, Eduard (ur.) (2011). Biografski leksikon Hrvata istočnog Srijema, sv. 1, Libera editio d.o.o.-Hrvatsko akademsko društvo, Zagreb-Subotica.

Hemar, Eduard (2016). Istarski sportski biografski leksikon, Sportska zajednica Istarske županije, Pula, 2016.

Enciklopedija Novog Sada, A-Š, sv. 1-30, Novosadski klub, Novi Sad, 1993-2009.

Hrvatski biografski leksikon, A-Li, 1-8, Leksikografski zavod Miroslav Krleža, Zagreb, 1983-2013.

Leksikon podunavskih Hrvata - Bunjevaca i Šokaca, A, sv. 1, Hrvatsko akademsko društvo, Subotica, 2004, 59 str. (drugo dopunjeno izdanje 2008, 63 str.).

Leksikon podunavskih Hrvata - Bunjevaca i Šokaca, B-Baž, sv. 2, Hrvatsko akademsko društvo, Subotica, 2004, str. 77.

Leksikon podunavskih Hrvata - Bunjevaca i Šokaca, Be-Br, sv. 3, Hrvatsko akademsko društvo, Subotica, 2005, 67 str.

Leksikon podunavskih Hrvata - Bunjevaca i Šokaca, Bu, sv. 4, Hrvatsko akademsko društvo, Subotica, 2005, 74 str.

Leksikon podunavskih Hrvata - Bunjevaca i Šokaca, C-Ć, sv. 5, Hrvatsko akademsko društvo, Subotica, 2006, str. 66 str.

Leksikon podunavskih Hrvata - Bunjevaca i Šokaca, D, sv. 6, Hrvatsko akademsko društvo, Subotica, 2006, str. 105 str. 
Leksikon podunavskih Hrvata - Bunjevaca $i$ Šokaca, Dž-F, sv. 7, Hrvatsko akademsko društvo, Subotica, 2007, str. 108 str.

Leksikon podunavskih Hrvata - Bunjevaca $i$ Šokaca, G, sv. 8, Hrvatsko akademsko društvo, Subotica, 2008, str. 78 str.

Leksikon podunavskih Hrvata - Bunjevaca i Šokaca, H, sv. 9, Hrvatsko akademsko društvo, Subotica, 2009, str. 230 str.

Leksikon podunavskih Hrvata - Bunjevaca $i$ Šokaca, I, sv. 10, Hrvatsko akademsko društvo, Subotica, 2010, str. 112 str.

Leksikon podunavskih Hrvata - Bunjevaca $i$ Šokaca, J, sv. 11, Hrvatsko akademsko društvo, Subotica, 2011, str. 121 str.

Leksikon podunavskih Hrvata - Bunjevaca i Šokaca, K-Knj, sv. 12, Hrvatsko akademsko društvo, Subotica, 2013, 200 str..

Leksikon podunavskih Hrvata - Bunjevaca i Šokaca, Ko-Kr, sv. 13, Hrvatsko akademsko društvo, Subotica, 2017, 162 str.

Leksikon podunavskih Hrvata - Bunjevaca i Šokaca, Ku-Kv, sv. 14, Hrvatsko akademsko društvo, Subotica, 2019, 103 str.

Mandić, Živko (1999). Zaboravi da si Šokac bio, Hrvatski kalendar 1999, Zemaljska samouprava Hrvata Budimpešta, b. g., str. 173-178.

Pekić, Petar (1930). Povijest Hrvata u Vojvodini od najstarijih vremena do 1929. godine, Matica Hrvatska, Zagreb.

Srpski biografski rečnik, A-Pan, sv. 1-7, Matica srpska, Novi Sad, 2004-2018.

Velin, Stipan (1999). Pokret santovačkih Hrvata potkraj 19. stoljeća, Hrvatski znanstveni zbornik, 2, Hrvatski znanstveni zavod, Pečuh, str. 80-99.

Zoričić, Krsto (2020). Grad Novi Vinodolski Prilozi za biografski leksikon, Grad Novi Vinodolski-Narodna čitaonica i knjižnica-Naklada Kvarner, Novi Vinodolski, 643 str.

Židovski biografski leksikon, https://zbl.lzmk.hr/ (pristupljeno 10. X. 2020) 


\title{
FEATURES OF THE CONCEPT OF BIOGRAPHICAL ARTICLES IN THE LEXICON OF THE DANUBE CROATS - BUNYEVCI AND ŠOKCI
}

\author{
Slaven Bačić \\ Croatian Academic Society, Subotica \\ slaven.bacic@yahoo.com
}

\begin{abstract}
A significant portion of the Lexicon of Danubian Croats - Bunjevci and Šokci, the first lexicographic project of a Croatian minority outside their mother country, regularly published in Subotica since 2004, consists of biographical articles. The specific form of this regional lexicon has led to a novel approach to the research and presentation of biographies, distinct from the biographical norms of national lexicography. The author summarises the essential conceptual features of the biographical articles presented in this lexicon. The entries include the individuals' parents' names, followed by an overview of how the link with their homeland place is reflected in their life, work, or scientific interest, to which their burial location may also testify. The author particularly emphasises why the inclusion criterion of Danubian Croats involves the principle of ethnic origin, rather than national sentiment, and compares conceptual differences between the biographies of Croats from Croatia and those of Danubian Croats, as geographically defined by the Lexicon (the area between rivers Danube and Tisa). The author also points out the importance of including the biographies of people belonging to other nations (Hungarians, Serbs) and describes the methodological conception of these articles. $\mathrm{He}$ also explains the absence of a lower age limit for inclusion in the Lexicon, conceptual differences between the treatment of historical figures and contemporaries, and other notable characteristics.
\end{abstract}

Keywords: The Lexicon of The Danube Croats - Bunjevci and Šokci; biographical articles; Danube Croats; Bunjevci; Šokci 